\title{
EFFECT OF NOZZLE TYPES, SPRAY VOLUMES AND RATE OF GLYPHOSATE ON DROPLET NUMBERS, DROPLET SIZES AND ITS EFFICIENCY ON WEED CONTROL IN CITRUS ORCHARDS \\ Moshtohry, M.R. ${ }^{1}$ and A.E.Ammar ${ }^{2}$ \\ 1-Weed Res. Central laboratory 2-Plant Protection Res. Institute, Spray technology dep. Agriculture Research Center , Giza, Egypt
}

\begin{abstract}
Two field experiments were carried out in Horticulture Research Station at El-Kanater , Kalubia Governorate during 2003 and 2004 summer seasons at Navel orange trees 15 years old orchard naturally heavily infested with annual and perennial weeds. Each experiment included eleven treatments in a complete randomized block design with four replicates. Four nozzles were applied in these treatments i.e. hollow cone ( conventional method) at rates of glyphosate ( Round up $48 \%$ WSC) $4.0,2.5 \mathrm{~L} / \mathrm{fed}$. and $1.25 \mathrm{~L} / \mathrm{fed}$., withTK 1 nozzle at 2.5 and $1.25 \mathrm{~L} / \mathrm{fed}$, flat and fan E $04-80$ nozzle at 2.5 and $1.25 \mathrm{~L} /$ fed . and deflector yellow nozzle at 2.5 and $1.25 \mathrm{~L} / \mathrm{fed}$. as compared with hand hoeing and unweeded check. Water volumes were $200,125,102$ and $50 \mathrm{~L} / \mathrm{fed}$. with the previous nozzles in the same respective. The aim of this study is to compare various nozzles types, spray volumes and glyphosate rates on number of droplets $/ \mathrm{cm}^{2}$, droplet size $\mu \mathrm{m}$ and weed control efficiency Results of study indicate that using TK1, flat fan E $04-80$ and deflector yellow nozzles can reduced glyphosate rate to $2.5 \mathrm{~L} / \mathrm{fed}$. by $37.5 \%$ compared with conventional method with hollow cone at $4.0 \mathrm{~L} / \mathrm{fed}$. without effect on weed control efficacy .These nozzles improved spray spectrum by increasing number of droplets to $35-57 / \mathrm{cm}^{2}$ in the first season and $39-55 / \mathrm{cm}^{2}$ in the second season and decreasing droplet size to $367-200$ and $360-205 \mu \mathrm{m}$ in the first and second seasons, respectively as compared to hollow cone nozzle which gave 17 and 20 droplet/ $\mathrm{cm}^{2}$ with 679 and $669 \mu \mathrm{m}$ for both seasons, respectively at the same rate of $2.5 \mathrm{~L} / \mathrm{fed}$. Control percentage which obtained by these nozzles were 93.2, 92.2 and $90.1 \%$ in the first season and 95.7, 94.5 and $93.5 \%$ in the second season, respectively, as compared with hollow cone which gave 94.3 and $97.2 \%$ for the first and second seasons at $4.0 \mathrm{~L} / \mathrm{fed}$., respectively. On the other hand the low rate of glyphosate at $1.25 \mathrm{~L} / \mathrm{fed}$. gave good efficacy in controlling annual weeds which reached $89 \%$ control percentage for these weeds and exceeded hand hoeing .

Thus it could be concluded that these nozzles can reduce spray volume and glyphosate rate without any significant reduction in the control efficacy of total weeds accompanied with homogeneous distribution and decreasing the amount of herbicide drift which fallen in non targets crops during the application and consequently decrease the pollution and other possible risks on the environment .
\end{abstract}

\section{INTRODUCTION}

The selection droplet of appropriate spraying equipment including the choice of nozzle types droplet size and droplet number is the most practical applying for herbicide usage where extremely small droplets have ability to fasten onto a surface than large ones, and evaporation loss is also important at the higher temperatures, very large droplets can not adhere to plants that are reactive to wetting particularly if the surface tension of spray is high.

Glyphosate is non-selective, translocated herbicide environmentally friendly for weed control in horticulture plantation, but potential of spray drift in 
these crops should be present in concern. Number of droplets and droplet size can play a good role in managing this problem as mentioned by many researchers as Barzee and Stroube (1972) found that liquid formulations of herbicides can be applied at low carrier volumes with weed control similar to that obtained with conventional application. Mckinly et al (1974), Caseley et al ( 1976 ) . Truelove ( 1977 ) mentioned that most herbicide applications are made with flat tips in used nozzles. Ambach and Ashford ( 1982 ) and Buhler and Burnside ( 1983 ) found that glyphosate efficacy increased when applied at lower carrier volumes as compared to standard carrier volumes. Gebhard et al ( 1985 ) showed that glyphosate at $>0.6 \mathrm{~kg} / \mathrm{ha}$ applied in $56 \mathrm{~L} / \mathrm{ha}$ with a volume median diameter of $298 \mu \mathrm{m}$ was more effective in control of weeds than when applied in 28L/ha with a volume median diameter of $238 \mu \mathrm{m}$. Ashton and Monaco ( 1991 ) indicated that glyphosate formulation that has been optimized for efficacy could result in smaller spray droplet, which can cause droplets to fall to surface much slower. Slow falling droplets could result in increased drift potential. Mueller and Womac ( 1997 ) mentioned that new nozzle technologies could provide a useful management tool to manage potential drift situation where the use of a pre-orifice flat fan nozzle and an impact type flat fan nozzle reduced the amount of small droplet size compared to an existing extended range flat fan nozzle, while maintaining a spray droplet distribution that could still provide good weed control. Feng et al (1998) and Ryerse et al ( 2001 ) showed that large droplet sizes of relatively concentrated herbicide induce epidermal disruption and localized cell necrosis . Bradford et al (2003) indicated that glyphosate efficacy increased as spray volume decreased from 190 to $23 \mathrm{~L} / \mathrm{ha}$. Low spray volumes maximized glyphosate efficacy primarily through high herbicide concentration in the spray deposit and reduced salts from the carrier to antagonize efficacy. Glyphosate applied in $23 \mathrm{~L} /$ ha spray volume with drift reducing nozzles provided control equal to that provided by glyphosate applied with standared flat fan nozzles. Feng et al (2003) reported that glyphosate absorption in corn leaves was directly correlated with droplet size. Percentages of translocation also increased with droplet size, and translocation was primarily toward strong sink tissues such as roots and young leaves. large droplets have slightly reduced retention in corn but have increased absorption resulting in increased translocation of glyphosate to growing sink tissues. Fietsam et al (2004) indicated that spray coverage of the weed canopy was reduced with use of the low drift nozzle where extended range flat fan ( XR ) $>$ pre-orfice flat fan ( DG ) > turbo flat fan ( TT ) > venturi flat fan

(PA ), spray droplet density was also generally reduced with the use of low drift nozzle .

In Egypt, farmers used to apply herbicide with different nozzle types causing phytotoxicity from drift which fall in non target crops or causing waste in herbicide use due to low retention of the largest droplet sizes. For this reason, the objective of this study was to compare the number of droplets / $\mathrm{cm}^{2}$, droplet sizes $\mu \mathrm{m}$, spray volume L./fed and rate of glyphosate L/fed. by TK1, flat fan and deflector yellow as compared with conventional methods of hollow cone on weed control in citrus orchards fields. 


\section{MATERIALS AND METHODS}

Two field experiments were carried out in El- Kanater Research Station Qalubia Governorate during 2003 and 2004 summer seasons naturally heavily infested with annual and perennial weeds to evaluate the performance of various nozzles, spraying patterns and glyphosate rate on droplet number, droplet size and weed control in citrus orchard ( Navel orange 15 years old).A complete randomized block design was used each year. The plot size was $30 \times 9 \mathrm{~m}$. Herbicide treatments were carried out at June 29 and July 21 for the first and second seasons, respectively. The herbicide used was glyphosate ( N-phosphonomethyl glycine) non selective, broad spectrum, post emergence, transracatid herbicide for annual and perennial weed control , its trade name is Round up $48 \%$ WSC. Each experiment included eleven treatments as follows :

1- Round up at $4.0 \mathrm{~L} / \mathrm{fed}$. with hollow cone nozzle at $200 \mathrm{~L}$ water /fed.

2- Round up at $2.5 \mathrm{~L} / \mathrm{fed}$ with hollow cone nozzle at $200 \mathrm{~L}$ water /fed.

3- Round up at $1.25 \mathrm{~L} / \mathrm{fed}$. with hollow cone nozzle at $200 \mathrm{~L}$ water /fed. .

4- Round up at $2.5 \mathrm{~L} / \mathrm{fed}$. with TK1 nozzle at $125 \mathrm{~L}$ water /fed .

5- Round up at $1.25 \mathrm{~L} / \mathrm{fed}$ with TK1 nozzle at $125 \mathrm{~L}$ water /fed .

6- Round up at 2.5L/fed .with flat fan E04-80 nozzle at $102 \mathrm{~L}$ water /fed

7- Round up at 1.25 L L/fed. with flat fan E04-80nozzle at $102 \mathrm{~L}$ water /fed.

8- Round up at $2.5 \mathrm{~L} / \mathrm{fed}$. with deflector yellow nozzle at $50 \mathrm{~L}$ water /fed.

9- Round up at $1.25 \mathrm{~L} / \mathrm{fed}$. with deflector yellow nozzle at $50 \mathrm{~L}$ water /fed.

10-Hand hoeing .

11-Unweeded check.

Spray nozzles were positioned $65 \mathrm{~L} \mathrm{~cm}$ above the ground, with spray speed of $2.4 \mathrm{~km} / \mathrm{hr}$. The flow rates were $2.86,1.79,0.81$ and $0.50 \mathrm{~L} / \mathrm{min}$ for hollow cone, TK1, flat fan E04-80 and deflector yellow nozzles respectively. Droplets were received on sensitive cards from Ciba Geigy company which distributed randomly onweeds as show in figure (1), ground and applicator. The program of calibration was suggested by Gabir et al (1982). Five wire holders were distributed and fixed in diagonal line mounted with sensitive cards which distributed also five on weeds and five on applicator ( one on head, two on thorax / abdomen and two on legs). Data of weeds were subjected to statistical analysis according to Snedecor and Cochran ( 1980 ). The least significant differences ( LSD)at $5 \%$ level of significance was calculated. 


\section{Data recorded}

All sensitive cards were collected carefully for measuring and calculating by special scaled monocular lens of struben with magnifiction of $\mathrm{X} 15$, droplet were recorded as follows :

1 - Number of droplets $/ \mathrm{cm}^{2}$ on weeds, ground and applicator .

2 - Droplet size ( $\mu \mathrm{m})$ on weeds, ground and applicator.

Weeds were survey and classified according to Tackholm ( 1974 ) and the following data were recorded.

1 - Fresh weight of annual broadleaf, grassy and total weeds/gm ${ }^{2}$

2 - Controlling percentage :-

$=$ Fresh weight in un weeded check - fresh weight in herbicide treatment $\times 100$

Fresh weight in unweeded check .

\section{RESULTS AND DISCUSSION}

A. Effect of nozzle types, spray volume and rate of glyphosate application on number of droplets $/ \mathrm{cm}^{2}$ and droplet size $\mu \mathrm{m}$.

The efficiency of various nozzles, spray volumes and rates of glyphosate on number of droplets and droplet size and its coverage on weed surfaces, ground and applicator were studied as shown in table 1 and figure 2.

The dominant annual broad leaf weeds in the experimental site for the two seasons were: Euphorbia geniculata Ortega, Xanthium spinosum L., Amaranthus hybridus L., Chenopodium album L. and Solanum nigrum L., while dominant annual grass weeds were Echinochloa colonum L., Setaria viridis L., Eleusine indica L. and Bromus sp. The perennial weeds were Cynodon dactylon $\mathrm{L}$. pers. and Cyperus rotundus $\mathrm{L}$.

\section{1-On weed surfaces:}

Results in table 1 show that the number of droplets $/ \mathrm{cm}^{2}$ was drastically affected by nozzle type and spray volume which increased with decreasing spray volumes that gave average 16, 37, 52 and 58 droplets $/ \mathrm{cm}^{2}$ with hollow cone, $\mathrm{Tk}_{1}$, flat fan and deflector yellow, respectively in the first season and $18,40,48.5$ and 58 droplets $/ \mathrm{cm}^{2}$ with the respective nozzle in the second season. On other hand droplet size tended to decrease with decreasing spray volume under various nozzles, where the average of droplet sizes were 678.5, 366, 341 and $197.5 \mu \mathrm{m}$ with hollow cone, Tk 1 , flat fan and deflector yellow nozzles, respectively in the first season, while it was 668, 359.5, 349 and $197.55 \mu \mathrm{m}$ for respective nozzles in the second season. Deflector yellow nozzle increased number of droplets $/ \mathrm{cm}^{2}$ to 59 and decreased droplet size to $195 \mu \mathrm{m}$ compared to hollow cone $15 \mathrm{droplet} / \mathrm{cm}^{2}$ and $680 \mu \mathrm{m}$. Ennis and Williamson (1963) indicated that small droplets have less ability to fasten onto a surface than large ones, and evaporation loss is also important at the higher temperatures. Very large droplets can not adhere to plants that are refractive to wetting particularly if the tension of spray is high. The herbicidal toxicity increased as the particle diameter increased from 300 to 1000 microns. Small droplets are deposited farther out board than the larger droplets (375 - 7000 microns) and these smaller droplets, emerging from the point $75 \%$ out to the wing tip, are entrained in trailing wing tip vortex thereby being dispersed over the country side, far from the spray swath. 
J. Agric. Sci. Mansoura Univ., 32 (7), July, 2007

F1 
Bradford et al (2003). reported that glyphosate efficacy increased as spray volume decreased from 190 to $23 \mathrm{~L}$ / ha .

\section{2-On ground:}

The same trend was observed that number of droplets $/ \mathrm{cm}^{2}$ were increased and vice versa droplet sizes were decreased with decreasing spray volume under various nozzles. There is no effect of glyphosate rate on these characters. This was true in both seasons.

\section{3- On the applicator:}

Data in table (1) exerted great reduction on number of droplets $/ \mathrm{cm}^{2}$ deposited on the applicator with the spray of glyphosate by flat fan E04-80 or deflector yellow nozzles by $81.8 \%$ in the first season and $69.2 \%$ in the second season as compared with hollow cone nozzle. These results suggest that the drift of spraying was less with the use of these nozzle types on non target organisms. The reduction on droplet size was 45.6 and $69 \%$ in the first season while it was 46.3 and $68.5 \%$ in the second season for the two previous nozzles, respectively compared to hollow cone nozzle at the rate of $2.5 \mathrm{~L} / \mathrm{fed}$. These results are in agreement with these obtained by Ashton and Monaco (1991), Mueller (1997), Brzadford et al (2003) and Fietsam et al (2004).

B. Effect of nozzle types, spray volume and rate of glyphosate on control efficacy for annual, perennial and total weeds:

\section{1- Annual weeds:}

Data in table 2 indicated that in general all rates of glyphosate under various nozzle types had no significant differences on the control of annual weeds. This was true in the first season except the rate of $1.25 \mathrm{~L} / \mathrm{fed}$ with deflector yellow nozzle which had no significant difference with hand hoeing. Thus the low rate of glyphosate gave good efficacy reach to $89 \%$ controlling of annual weeds. In the second season $\mathrm{Tk}_{1}$, flat fan and deflector yellow nozzles did not differ significantly and gave 95.6, 94.1, and 93.3\% control, respectively at $2.5 \mathrm{~L} / \mathrm{fed}$. similar to hollow cone nozzle at $4.0 \mathrm{~L} / \mathrm{fed}$. which gave $97.3 \%$ control. Low rate at $1.25 \mathrm{~L} / \mathrm{fed}$ gave $79.7,81.1,80.2$ and $76.5 \%$ control for hollow cone, $\mathrm{Tk}_{1}$, flat fan and deflector yellow nozzles respectively and exceeded hand hoeing treatment.

\section{2-Perennial weeds:}

As shown in table (2) all nozzles gave similar results on controlling perennial weeds without significant differences at the high rate of glyphosate 4.0 and $2.5 \mathrm{~L} / \mathrm{fed}$. with hollow cone and $2.5 \mathrm{~L} / \mathrm{fed}$. with TK1, flat fan and deflector yellow nozzles in both seasons which gave control percentage ranged from $89.5 \%$ to $97.1 \%$. Also there are no significant differences between various nozzles in both seasons at the low rate $1.25 \mathrm{~L} / \mathrm{fed}$. except hollow cone nozzle in the second season which had no significant differences with flat fan and deflector yellow nozzles that ranged from $71.5 \%$ to $81.6 \%$. High rate of glyphosate gave the best effect in weed control of perennials and significantly exceeded low rates with different nozzles and spray volumes.

\section{3-Total weeds:}

Data in table 2 show that all nozzles i.e hollow cone, $\mathrm{Tk}_{1}$, flat fan and deflector yellow gave the best results in weed control of total weeds at the 
high rates of glyphosate in both seasons by $94.3,93.2,92.2$ and 90.1 in the first season, while it was 97.2, 95.7 , 94.5 and $93.5 \%$ in the second season, respectively. On the other hand hollow cone nozzle gave significantly lower results in weed control of total weeds at the rate of $2.5 \mathrm{~L} / \mathrm{fed}$. compared with other nozzles at the same rate in both seasons ( Figure 2). 
Moshtohry, M.R. and A.E.Ammar

T1

5630 
J. Agric. Sci. Mansoura Univ., 32 (7), July, 2007 T2 
It was observed from the results in table 1 and 2 or figure 1 and 2 that with decreasing spray volume accompanied with decreasing droplet size and increasing number of droplets at rate of $2.5 \mathrm{~L} / \mathrm{fed}$ with nozzles types $\mathrm{Tk}_{1}$, flat fan and deflector yellow which gave similar efficacy of weed control of annual, perennial and total weeds at the high rate at $4.0 \mathrm{~L} / \mathrm{fed}$. with hollow cone nozzle. The present results suggest that TK1, flat fan E04 - 80 and deflector yellow nozzles with Round up at the rate of $2.5 \mathrm{~L} / \mathrm{fed}$. can decrease droplet sizes from 690-695 to 329-359 $\mu \mathrm{m}$ when compared whit conventional hollow cone nozzle with similar efficacy of weed control with the high rate of Round up at 4.0L/fed. Feng et al ( 2003 ) mentioned that glyphosate absorption and translocation are correlated with herbicide droplet size. Mueller and Womac ( 1997 ) indicated that glyphosate efficacy can be optimized by using the various nozzles though producing smaller droplets .

The present results suggest that TK1, flat fan E04 - 80 and deflector yellow nozzles with Round up at the rate of $2.5 \mathrm{~L} / \mathrm{fed}$. can decrease droplet sizes from 690-695 to 329-359 $\mu \mathrm{m}$ when compared with conventional hollow cone nozzle with similar efficacy of weed control with the high rate of Round up at $4.0 \mathrm{~L} / \mathrm{fed}$.

These results are in harmony with those obtained by Barzee and Stroube (1972), Mckinlay et al (1974), Caseley et al (1976), Ambach and Ashford (1982) Buhler and Burnside (1983) Gebhdrdt et al (1985), Ashton and Monaco (1990), Muetter and Womac (1997). Bzadford et al (2003) mentioned that glyphosate efficacy increased when applied at lower carrier volumes with specific nozzle as compared to standard carrier volumes. In other hand the low rate of Roundup ( 1.25) l/fed can be used as alternative to hand hoeing in controlling annual weeds. The high sensitivity of annual species to low rate of glyphoscete is attributed to less lignified tissues in annual weeds than in perennial weeds .

\section{Conclusion}

It could be concluded from the result that applying glyphosate at the rate of $2.5 \mathrm{~L} / \mathrm{fed}$. with TK1, flat fan E04 -80 and deflector yellow nozzles reduced droplet sizes $\mu \mathrm{m}$ and vice versa increased number of droplets $/ \mathrm{cm} 2$ suitable for good distribution of droplets on weed leaves enough for control of broadleaves and grassy weeds similar to that oltained with hollow cone nozzle when applied at the high rate at $4.0 \mathrm{~L} / \mathrm{fed}$. The low rate of glyphosate applied at $1.25 \mathrm{~L} / \mathrm{fed}$.was effective and sufficient in controlling annual weeds with the use of obvious nozzles.

\section{REFERENCES}

Ambach, R . M . and Ashford ( 1982) Effects of variation in drop make up on the phytotoxicity of glyphosate Weed sci.30:221-224 .

Anonymous (1988) PCPC Nozzle selection hand book. British Crop Protection Council Farnham, U.K. 40 pp.

Ashton, F.M. and T.J. Monaco (1991) Nitriles, phenoxies and pyridazinones. In Weed Science Principles and Practices $3^{\text {rd }}$ ed. New York NY: Wiley Interscience Publishers ;. 246-247. 
Barzee, M.A. and E.W. Stroube (1972) Low-volume application of pre emergence herbicides. Weed Sci. 20: 176-180.

Bradford,KR,C.G Messersmith and J.D. Nalewaja (2003) Spray volume ,formulation, ammonium sulfate and nozzle effects on glyphosate efficacy .Weed Technol . 17:589-598.

Buhler, D.D. and D.C. Burnside (1983) Effect of spray components of glyphosate toxicity to annual grasses. Weed Sci. 31: 124-130.

Caseley, J.C. and D. Coupland (1985) Environmental and plant factors affecting glyphosate uptake, movement and activity . pages 92-123 in E Grossbard and D. Arkinson. eds. The herbicide Glyphosate. London: Butterworth.

Caseley, J.C. and D. Coupland and R.C.Simmons (1976) Effect of formulation, volume rate and application method on performance and rainfastness of glyphosate on Agropyron repens Proc. Brit. Crop Prot. Conf. Weeds : 407-412.

Ennis,W.B and R.E. Williamson (1963) The influence of drop size on effectiviness of low volume herbicidal spray. Weeds, 11,67-72.

Felton, W.L., A.F. Doss, P.G. Nash and K.R. Mc Cloy (1991) A microprocessor controlled technology to selectivity spot spray weeds Pages. $427-431$ in Automated Agric. For the $21^{\text {st }}$ Century Symp. Amer. Soc. Of Agric. Eng. Fargo, ND: Concord.

Feng, P.C.C., T. Chiu, R.D. Sammons and J.R. Ryerse (2003) Droplet size affects glyphosate retention, Absorption and translocation in corn. Weed Sci. 51: 443-448.

Feng, P.C.C., J.S. Ryerse and R.D. Sammons (1998) Correlation of leaf damage with uptake and translocation of glyphosate in velvetleaf (Abutilon theophrasti) Weed Technol. 12: 300-307.

Fietsam, J.F.W, B.G Young and R.W.Steffen ( 2004 ) Differential response of herbicide drift reduction to drift control agents with glyphosate. Transactions of the ASAE 47(5): 1405-1411.

Gabir, I., Z.H. Zidan, E. Attallah and M.A. Hindy (1982) Calibration and evaluation of the performance of certain hydraulic nozzle types under laboratory conditions. Res. Bull. 1738 Fac.Agric.Ain Shams Univ.pp 19.

Gebhardt, M.R , C.L, Webber and L.F. Bouse (1985) Comparison of a rotary atomizer to a fan nozzle for herbicide application. Translations of the ASAE pp 382-397.

Muller, T.C and A.R , Womac (1997) Effect of formulation and nozzle type on droplet size with isopropylamine and timesium salts of glyphosate. Weed Technol. 11: 639-643.

Mckinlay, K.S,R. Ashford and R.J. Ford (1974) Effects of droplet size, spray volume and dosage on paraquat toxicity. Weed Sci. 22: 31-34.

Osman, G. (1983) Determination and calculation of droplets in the control of agricultural pests. M.Sc. thesis, Fac. Agric. Ain Shams Univ. pp .94.

Ryerse J.S., P.C.C. Feng and R.D. Sammons (2001) Endogenous fluorescence identifies dead cells in plants. Microsc. Today 1:24-

Snedecor. W and W-G Cochran (1980) Statistical Methods . $7^{\text {th }}$ ed. lowa state unit ., lowa , USA. 
Tackholm , V. (1974) Students flora of Egypt $2^{\text {nd }}$ ed . Cairo univ, Egypt Graphical Service Beirut Lebanan pp 888 .

Truelove B. (1977) Weed research methods in weed science. $2^{\text {nd }}$ ed. Auburn, Alabama pp 221.

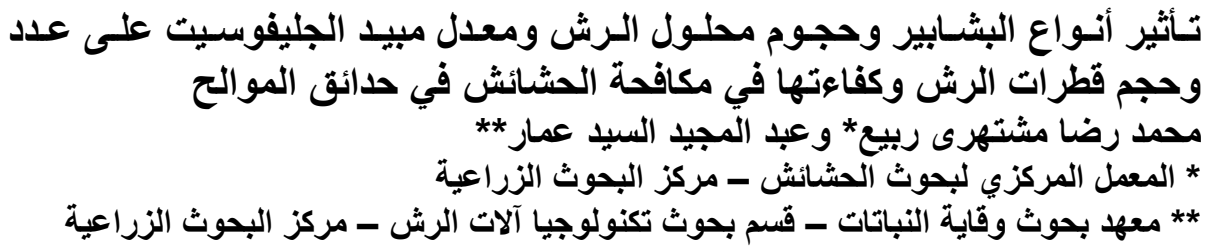

أجريت تجربتين حقليتين في محطة بحوث البساتين بالقناطر بمحافظة القليوبية في الموسم

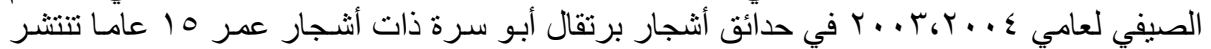

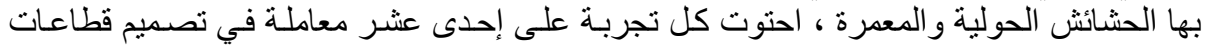

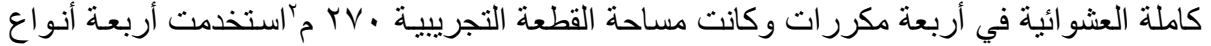

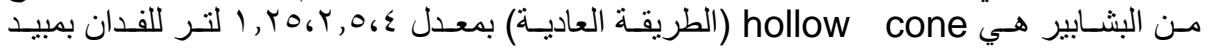

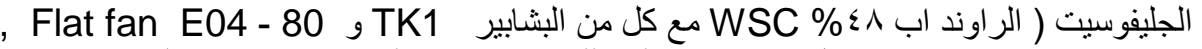

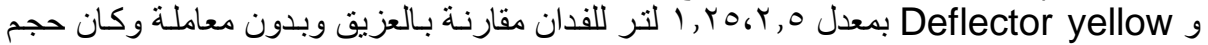

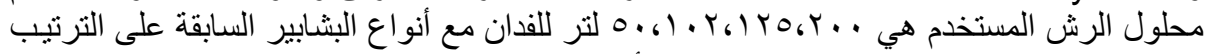

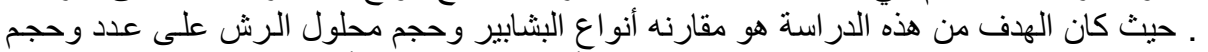

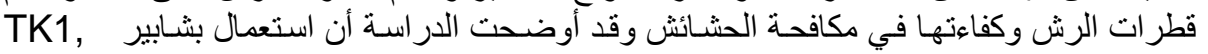
Flat, fan, E04-80, deflector yellow

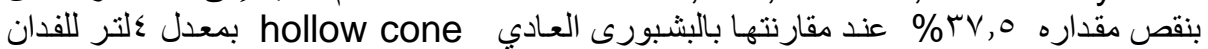

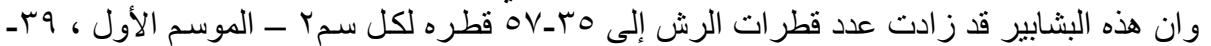

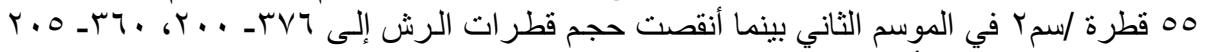

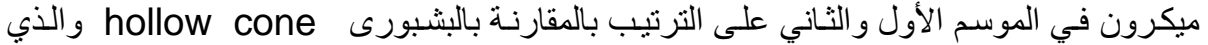

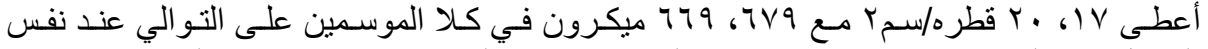

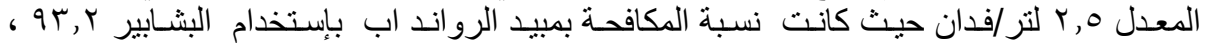

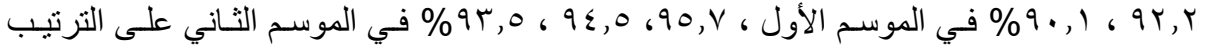

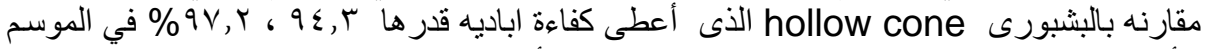

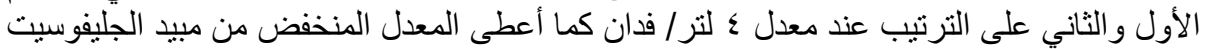

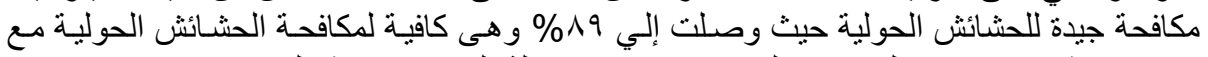

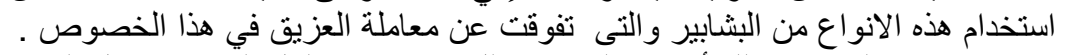

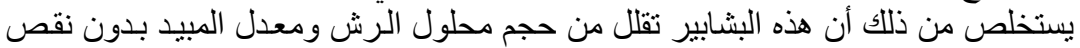

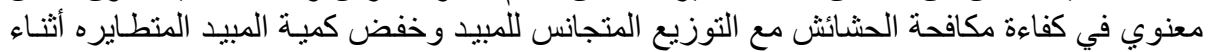

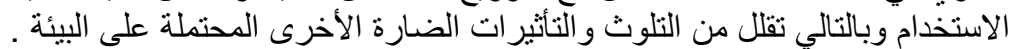

